\title{
Agricultural Bio-Stimulant Activity of Fish Protein Hydrolysate from Common Silver Belly (Gerres subfasciatus)
}

Srinivasan S, Devika $\mathbf{R}$ and Shanmugam $\mathbf{M}^{*}$ Research and Development Division (DSIR-Lab), AquAgri Processing Private Limited, Tamil Nadu, India *Corresponding author: Shanmugam M, Research and Development Division (DSIR-Lab), AquAgri Processing Private Limited, Manamadurai-630606, Tamil Nadu, India

Received: July 26, 2021; Accepted: August 26, 2021; Published: September 02, 2021

\begin{abstract}
Taking into account of using the fish industry wastes and for expanding the incentive to a few under used fish species, protein hydrolysates from fish proteins are being set up by a few specialists everywhere throughout the world. Fish Protein Hydrolysates (FPH) are breakdown results of enzymatic transformation of fish proteins into smaller units like peptides, which typically contain 2-20 amino acids. Their worth has been expanded by utilizing them as fluid bio compost, feed supplement and bioorganic fertilizer. From the research carried out at our laboratory, Dry fish silver belly with both microbe and enzyme acquired from cultural broth of lactobacillus species, catalyst papain demonstrated positive upgrade of development and advancement of plants tested. In view of the yield of FPH concentrates from both microbial and enzymatic hydrolysis, the pace of seedling life list in Urad dhal, green gram and okra got higher in 0.1-0.5\% convergence of dry fish hydrolysate from lactobacillus treated than in the control variation. With respect to the seeds of urad dhal, green gram and okra, the germination rate and seedling energy list from treated seeds surpassed control by $19.11-128.71 \%$. The positive effect of dry fish protein hydrolysate by microbial procedure on germination rate, seedling life record rate in 3 kinds of seeds is the reason for the improvement of protein hydrolysate item for application in crop creation utilizing dry fish squanders. The Seedling grown in $0.5 \%$ concentration of fish hydrolysates showed significant increase in seedling vigour index of Urad dhal (13.29 $\pm 0.12 \%)$, Green gram (14.1 $\pm 0.17 \%)$ and Okra (5.39 $\pm 0.43 \%$ ) was recorded through one way Analysis of Variance (ANOVA). By HPLC determination amino acid results determined that protein hydrolysates process can be stopped on $7^{\text {th }}$ day $(643.56 \mathrm{ppm})$ whereas @ $10^{\text {th }}$ day amino acid decreased (326.24ppm). Results suggest that probiotic assumes a superior job in dry fish protein hydrolysates than compounds when contrasted and yield and prudent astute.
\end{abstract}

Keywords: Silver belly; Enzymatic hydrolysis; Protein hydrolysates; Amino acid profile; Agro bio-stimulant

\section{Introduction}

Every year around 91 million tons of fish are collected of which fish dinner about $29.5 \%$ is changed [1,2]. Over half of the rest of the fish tissue viewed as waste and not taken as nourishment [3]. Traditionally fish squander has additionally utilized as a manure creating nutritive components ( $\mathrm{N}$ and $\mathrm{P}$ ) and their speedy decay. Numerous activities utilizing fish squander came about mostly from aquaculture have turned out in various pieces of the world in looking of inconsequent and significant procedures for changing over fish squander into helpful farming items [4-6]. Fish waste from farm upsets the region in and around legitimately brought about by the effluent. Yet in addition changes an expansive waterfront zone at different biological system levels, along these lines diminishing the biomass, tiny fish and nekton $[7,8]$ thickness and assorted variety of benthos, adjusting characteristic nourishment networks.

As per the report in 2009 , fish contributed about $16.6 \%$ of the world's complete admission of creature protein yet just $6.5 \%$ of all the protein exists on the planet [9]. Practically the majority of the fish wastes are arranged in the sea. Natural issue was separated by the high-impact microbes present in the water prompting a gigantic decrease of oxygen in water. Different in $\mathrm{pH}$ by over-burdens of $\mathrm{N}, \mathrm{NH}_{3}$ and $\mathrm{P}$ raised turbidity of water and because of this alga, deterioration happens. Because of decrease in water, oxygen content created anaerobic condition which prompts the arrival of $\mathrm{H}_{2} \mathrm{~S}$ and $\mathrm{NH}_{3}$, natural corrosive, $\mathrm{CO}_{2}, \mathrm{CH}_{4}[10]$.

The majority of the fish contains $15-30 \%$ of protein, $0-20 \%$ of fat substance and Moisture 50-80\% [11]. Amino corrosive arrangement was even in fish protein. 16-18 amino corrosive in fish rely on the species and regular varieties $[12,13]$. Because of high amino corrosive substance in fish, it has been utilized as fish sauce, fish supper, creature feed, fish silage and manure [14]. Roughly, the loss from fish handling plant recorded to 20 million tons that is equivalent to $25 \%$ of the world's absolute creation from fisheries catching region [15]. For instance nutritive estimation of silver paunch fish involved Moisture91g; fat-19g; Mineral-2g; fiber-3g; starch-0g; Calcium-715mg; 
phosphorous-741mg; iron-2mg [16]. FPH treatment at 2ml/L had also been shown to increase seed vigour, Guaiacol Peroxidase (GuPX) activity, Glucose-6-Phosphate Dehydrogenase (G6PDH) activity and phenolic content in pea during its earlier stages of germination [17].

The past research contemplates investigated the enzymatic handling of fish protein is by all accounts lab or little scope oriental however there is limitation when scaled up to huge scope [18]. Because of the nearness of fundamental supplements and bioactive segments in fish protein hydrolysates, these find place in different modern applications. Protein hydrolysates are breakdown results of enzymatic change of proteins into littler peptides. These protein hydrolysates are delivered by the enzymatic hydrolysis of local proteins [19]. Laboratory has been researching the impact of Fish Protein Hydrolysates (FPH) on seedling power [20]. Nations like Japan, France and a few nations like South-East Asia were done enormous scope creation of fish protein hydrolysate. In any case, the procedure has a few weaknesses like essential significant expense of catalysts, low yields, and chemical inactivation after hydrolysis by $\mathrm{pH}$ or by heat lastly the powerlessness to reuse proteins [21]. Extraction of protein by compounds is completed under settled $\mathrm{pH}$ condition without upsetting their wholesome characteristics for the acknowledgment in the enterprises like nourishment, and wide range of items can be produced for an expansive scope of uses [22].

Use of protein hydrolysates in a wide assortment of employments in ventures like nourishment, protein supplements, enhance enhancers, drink as stabilizers and milk replacers industry. Business fish waste or dry fish were utilized to deliver fish silage by microbial processing under anaerobic maturation estimated $50 \mathrm{~g}$ or $50 \mathrm{ml} / \mathrm{kg}$ LB culture and $150 \mathrm{~g}$ or $150 \mathrm{ml} / \mathrm{kg}$ sugarcane molasses [23]. The basic Silver stomach is types of significant which is the local spot of Pacific and Indian seaside waters of Australia. Its morphological structure is Silver shaded body, which can grow up to $20 \mathrm{~cm}$ long. It circulates from Southwestern Australia in the area of the tropical north of Australia and in the south on the east coast to Southern New South Wales.

The target of this investigation is to decide the ideal conditions for the protein hydrolysate creation procedure of dry fish protein by compound and probiotic culture. Just as investigation intended to assess the amino corrosive structure of fish protein hydrolysate delivered under different fixation levels in a period subordinate way. In the meantime, the preliminary utilizing Probiotic culture proceeded for additional 10 days to watch the amino corrosive profile content in the up and coming days (third day, seventh day and tenth day). Amino corrosive profile content was totally concentrated by HPLC 1260 Infinity II in crude material, Quick wash, third day, seventh day, tenth day and tenth day of the buildup).

\section{Materials and Methods}

For the whole experimental study, specifically the common silver belly species of dry fish were collected from the place Mandapam (Tamilnadu) Coastal region. Collected dry fish moved to AquAgri Processing Pvt. Ltd, Manamadurai, Tamilnadu to carry out further process. Both enzymes and probiotic based processes carried out in common silver belly dry fish.

\section{Sample preparation}

The materials were rinsed with water in the ratio of $1: 2$ to remove the impurities and other foreign materials. Washed dry fish were chopped into small pieces before homogenized.

Preparation of fish protein hydrolysates (FPH): The planning of Dry fish protein hydrolysate was led by the technique for klompong et al. with the change. The dry fish and water (1:3) (W/W) were utilized for the homogenization procedure. The minced dry fish treated with different centralizations of compounds at different temperatures in time subordinate way. After treatment, the filtrate sifted through muslin material. In protein process, the filtrate was warmed at $90^{\circ} \mathrm{C}$ for $20 \mathrm{~min}$ so as to inactivate the endogenous chemical and mixed constantly utilizing an attractive stirrer. Remaining buildup dried under daylight and grounded. The Same washed dry fish was treated with probiotic culture with different centralizations of the substrate (Jaggery) for $72 \mathrm{hrs}$. In the interim dry fish without catalyst and probiotic culture were treated as control.

Enzymatic hydrolysis: Papain catalyst (B.No: VS/PAP 01/001) is bought from V Sthiraa Bioscience E-101, Jay Ambe Residency, B/H. Anand Vatika, Mota Varachha, Dist-Surat, Gujarat (India). Enzymatic hydrolysis completed at different convergences of papain proteins under time subordinate way and different temperatures based. Different Concentrations of catalyst (2\%, $4 \%$ and $6 \%$ ) followed for the investigation with different temperatures $\left(40-45^{\circ} \mathrm{C}, 60-65^{\circ} \mathrm{C}\right.$, $75-80^{\circ} \mathrm{C}$ ). Treatment completed at a time interim of 5 hours, 10 hours and 15 hours.

Microbial digestion of dry fish: Lactic acid bacteria used in dry fish protein hydrolysis with various concentrations of Jaggery substrate. Lactic acid bacteria were isolated through rice wash water method and the isolated culture was enriched with 30\% of Jaggery to keep virulent for further use. Isolated colonies on MRS agar gram stained and biochemical tests carried out to confirm the species level.

\section{Physico-chemical parameter analysis}

Moisture content: Moisture content of the sample was determined by placing approximately $2 \mathrm{~g}$ of sample into a pre weighed petri dish. Samples kept in an oven and dried at $105^{\circ} \mathrm{C}$ for $4-5$ hours until constant weight obtained [24].

Quantification of Amino acid through HPLC: Acetonitrile (LC grade), methanol (LC grade) and LC grade Millipore water were purchased. Borate buffer, OPA and FMOC reagents and standard solutions of mixture of 17 amino acids (25, 100, 250 and 1000 $\mathrm{nmol} \mathrm{cm}{ }^{-3}$ ) were obtained from Agilent Technologies (Waldbronn, Germany). Hydrochloric acid, used for the preparation of $6 \mathrm{~mol} \mathrm{dm}^{-3}$ and $0.1 \mathrm{~mol} \mathrm{dm}^{-3} \mathrm{HCl}$, was obtained Cellulose membrane syringe filter $(0.22 \mu \mathrm{m}$ pore size), screw cap vials and screw caps were purchased from Agilent Technologies (Waldbronn, Germany). The analysis was performed on an Agilent 1260 Infinity 11 liquid chromatography system, equipped with a 1260 Quaternary pump (G7111B), 1260 standard auto sampler (G1729A), 1260 thermo stated column compartment, 1260 diode array and multiple wavelength detector (G7115A), and a Poroshell 120 EC-C18 column $(100 \mathrm{~mm} \times 4.6 \mathrm{~mm}$, i.e., particle size $2.7 \mu \mathrm{m}$ ) (Agilent Technologies). Fish hydrolysate was analyzed for their amino acid content. The solutions were filtered through quantitative filter paper into glass tubes and the filtrates were 
Table 1: Detail of the trial code and their treatment.

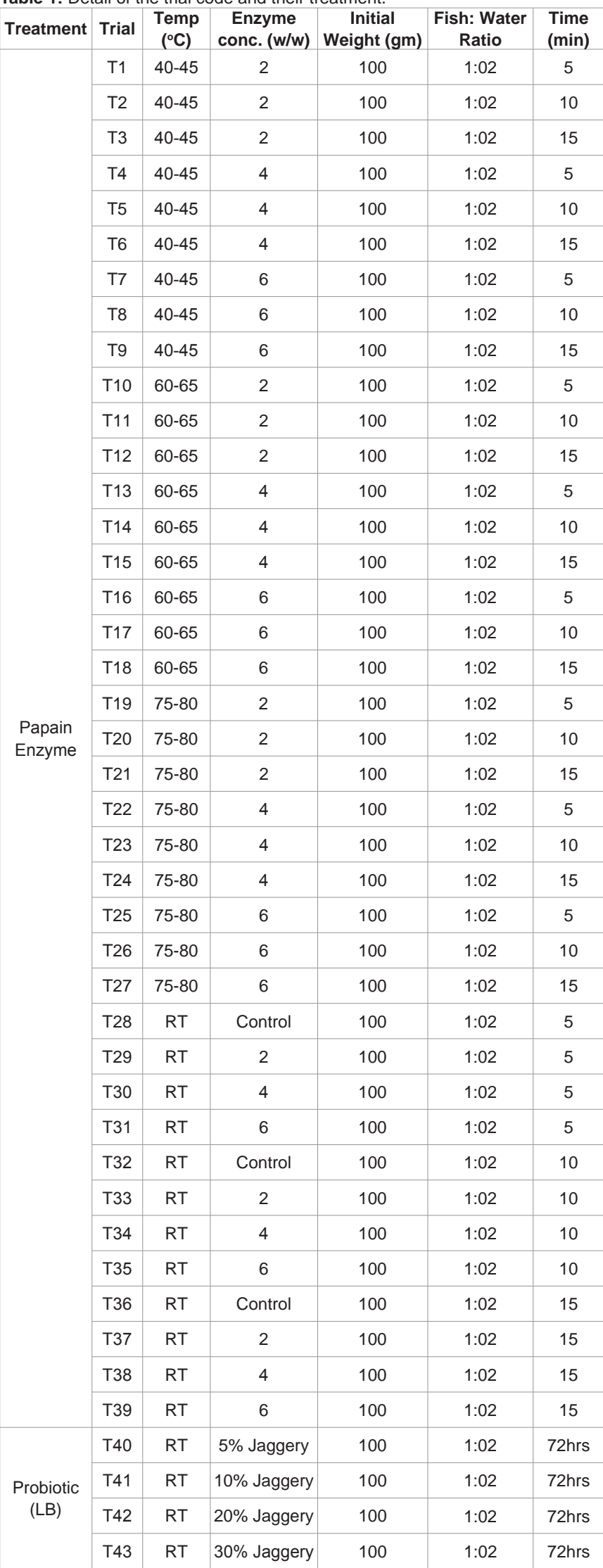

purified using $0.22 \mu \mathrm{m}$ pore size, cellulose membrane syringe filter [21].

HPLC Determination: The chromatographic conditions employed were in accordance with the Agilent method [22]. The mobile phase A consisted of $5.678 \mathrm{~g}$ of $\mathrm{Na}_{2} \mathrm{HPO}_{4}+15.2 \mathrm{~g}$ of $\mathrm{Na}_{2} \mathrm{~B}_{4} \mathrm{O}_{7} .10 \mathrm{H}_{2} 0$ ) per 4 liters of water, adjusted to the $\mathrm{pH} 8.2$ with Conc. $\mathrm{HCl}$ solution. The mobile phase $\mathrm{B}$ was acetonitrile-methanol-water (45:45:10, vol. \%). Briefly, the hydrolyzed samples or the solutions the standard amino acid mixture were automatically derivatised with OPA and FMOC by programming the autosampler (1. draw $2.5 \mu \mathrm{l}$ from vial 1 (borate buffer); 2 . draw $0.5 \mu$ from sample (position $\mathrm{X}$ ); 3 . mix $3 \mu l$ in air, max. speed, $2 \times$; 4 . wait $0.5 \mathrm{~min}$; 5 . draw $0 \mu \mathrm{l}$ from vial 2 (water, uncapped vial); 6. draw $0.5 \mu \mathrm{l}$ from vial 3 (OPA); 7. mix $3.5 \mu \mathrm{l}$ in air, max speed, $6 \times ; 8$. draw $0 \mu$ from vial 2 (water, uncapped vial); 9. draw $0.5 \mu \mathrm{l}$ from vial 4 (FMOC); 10 . mix $4 \mu \mathrm{l}$ in air, max speed, $6 \times$; 11. draw $32 \mu \mathrm{l}$ from vial 5 (water); 12 . mix $18 \mu \mathrm{l}$ in air, max speed, $2 \times$ and 13. inject). After derivatisation, $0.5 \mu \mathrm{l}$ of each sample was injected into a Poroshell column at $40^{\circ} \mathrm{C}$, with detection at $\lambda 1=338 \mathrm{~nm}$ and $\lambda 2=262 \mathrm{~nm}$

Sample Preparation for HPLC analysis: Ten grams of solid material of dry fish and $40 \mathrm{ml}$ of extracting solvent (75\% methanol in distilled deionized water) were added to a Mason jar and blended for $2 \mathrm{~min}$. The homogenate was then transferred to a $100 \mathrm{ml}$ volumetric flask and then the jar rinsed three times with water, which was then brought up to volume and stored overnight at $4^{\circ} \mathrm{C}$. The contents of the flask were transferred to a $50 \mathrm{ml}$ centrifuge tube and centrifuged at $15000 \mathrm{rpm}$ for $40 \mathrm{~min}$. The supernatant was filtered using Nylon $0.2 \mu \mathrm{m}$ filter membrane and treated as per standard solution. The liquid extract was transferred to a $50 \mathrm{ml}$ centrifuge tube and centrifuged at $5000 \mathrm{rpm}$ for $30 \mathrm{~min}$. The supernatant was filtered through Nylon $0.2 \mu \mathrm{m}$ filter membrane and treated as per standard solution [25].

\section{Efficacy study}

To consider the adequacy of LB processed protein hydrolysate, germination study completed by seed treatment process. Roughly, 10 seeds treated with different groupings of dry fish protein hydrolysate $(0.1,0.5,1.0,1.5$, and $2.0 \%)$. Randomly selected seeds like Urad dhal, Green gram, Okra were absorbed referenced above fixations for 60 minutes. The treated seeds were placed in the germination sheet for observation.

\section{Statistical analysis}

Statistical analysis of the data was performed by one way ANOVA. Data sets with $\mathrm{P}$ values $<0.05$ or $<0.1$ were considered statistically significant. The experiment was repeated for five times and the data sets combined for analysis.

\section{Results}

Total solids of fish hydrolysate calculated at various concentrations in a time dependent manner and temperature. According to time dependent manner, enzyme concentration of $2 \%$ at $60-65^{\circ} \mathrm{C}$ for 5 hrs have shown the highest TS value when compared with other time duration (10hrs \& 15hrs). Reduction in total solid at higher temperature in all concentration of enzyme is illustrated in Table 3. Results obtained for 3 different control under 3 different time duration (5,10 and $15 \mathrm{hrs})$ have shown that the gradual increase 
Table 2: Total Solid content of the various trials.

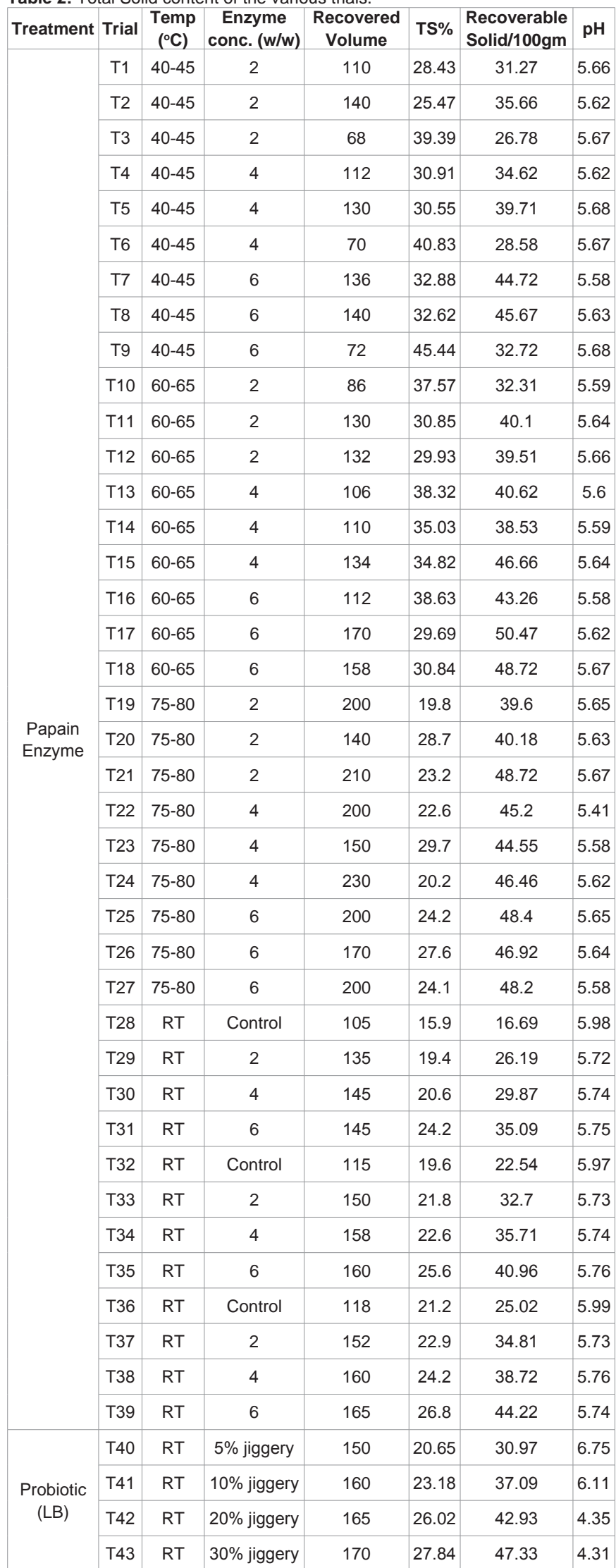

in TS from 5 to 15 hrs with $15.9 \%, 19.6 \%$ and $21.2 \%$ respectively. But on treated $\left(60-65^{\circ} \mathrm{C}\right.$ at $2 \%$ for 5 hrs $)$ have shown the higher TS value $(37.57 \%)$. In probiotic culture with various concentration of substrate Jaggery (5\%, 10\%, 20\% and 30\%) have shown highest TS value of $27.84 \%$ after 3 days with $\mathrm{pH}-4.31$ in 30\% substrate Jaggery added. Control (without adding of probiotic culture with a substrate Jaggery) was quickly contaminated within $24 \mathrm{hrs}$.

\section{Influence of DFH on germination}

The germination percentages, average seedling height and seedling vigour index of Urad dal, Green gram and Okra seeds following the DFH treatment are shown in the Table 3. Development of root length and shoot length in treated seeds compared with control. In treated urad dal seed $100 \%$ of seed germination rate at maximum number of concentration $(0.1,0.5,1.0$ and $1.5 \%)$ whereas in control $86 \pm 5.48 \%$ of seed germination was observed. As expected, $80 \pm 7.07 \%$ of seed germination occurred in highest concentration $(2 \%)$, it meant that it has shown the suppressing activity of seed. It was shown in Figure 1. All seedlings appeared to respond positively at lowest concentration $(0.5 \%)$ of DFH. Similarly, in green gram higher SVI $(14.14 \pm 0.17 \%)$ in $0.5 \%$ concentration, which is significantly correlated with control in which it was only $6.66 \pm 0.55 \%$, was obtained and shown in Figure 2. In okra seed $76 \pm 5.48 \%$ and $96 \pm 5.48 \%$ of the seed germination was obtained in control and $0.5 \%$ respectively. SVI have shown the highest rate of $5.39 \pm 0.43 \%$ at $0.5 \%$, control with $2.80 \pm 0.28 \%$ and $1.91 \pm 0.47 \%$ at $2 \%$, which was observed in Figure 3 .

\section{Amino acid profile content}

Amino analysis report was predicted for 8 number of samples include commercial product I (Amino acid rich Sap), commercial product II (Fish hydrolysate), papain enzyme treated dry fish hydrolysate liquid \& residue and Probiotic treated dry fish hydrolysate liquid \& residue. High protein content was observed in Probiotic Lactobacillus residue when compared with other samples. Total Solid $(42.53 \%)$ and Protein content $(24.98 \%)$ was rich in commercial product II liquid sample whereas papain enzyme treated liquid sample have shown TS - 15.96\% and Protein - 11.27\%. Alike Probiotic treated liquid sample have shown TS $-18.29 \%$ and Protein $-5.64 \%$. Both the residues of papain enzyme treated (Protein content - 48.57\%) and Probiotic treated residue (Protein content - 57.33\%) have shown the highest protein content compared with other liquid hydrolysate sample. Amino acid profiles of both enzymatic hydrolysis and Probiotic hydrolysis of dry fish are individually recorded in the Table

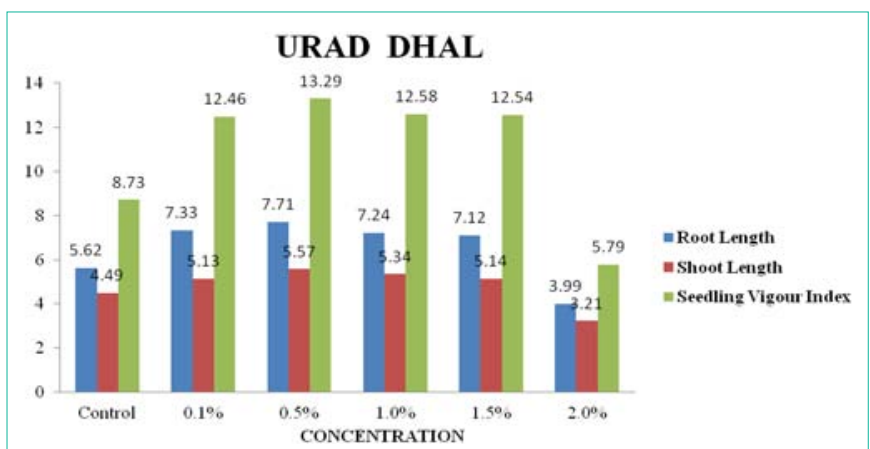

Figure 1: Different Concentration of Fish Hydrolysate on germination of Urad dhal. 
Table 3: Germination percentage by treatment.

\begin{tabular}{|c|c|c|c|c|c|c|}
\hline Seed & Concentration of DFH & Root Length & Shoot Length & Plant Length & Germination Percentage & Seedling Vigour Index \\
\hline \multirow{6}{*}{ Urad Dal } & Control & $5.62 \pm 0.64$ & $4.49 \pm 0.31$ & $10.11 \pm 0.92$ & $86 \pm 5.48$ & $8.73 \pm 1.28$ \\
\hline & 0.1 & $7.33 \pm 0.39$ & $5.13 \pm 0.24$ & $12.46 \pm 0.60$ & $100 \pm 0$ & $12.46 \pm 0.60$ \\
\hline & 0.5 & $7.71 \pm 0.09$ & $5.57 \pm 0.11$ & $13.29 \pm 0.14$ & $100 \pm 0$ & $13.29 \pm 0.14$ \\
\hline & 1 & $7.24 \pm 0.12$ & $5.34 \pm 0.05$ & $12.58 \pm 0.10$ & $100 \pm 0$ & $12.58 \pm 0.10$ \\
\hline & 1.5 & $7.12 \pm 0.14$ & $5.14 \pm 0.08$ & $12.25 \pm 0.19$ & $100 \pm 0$ & $12.54 \pm 0.19$ \\
\hline & 2 & $3.99 \pm 0.38$ & $3.21 \pm 0.23$ & $7.19 \pm 0.61$ & $80 \pm 7.07$ & $5.79 \pm 0.96$ \\
\hline \multirow{6}{*}{ Green Gram } & Control & $5.25 \pm 0.08$ & $3.52 \pm 0.14$ & $8.76 \pm 0.14$ & $76 \pm 5.48$ & $6.66 \pm 0.55$ \\
\hline & 0.1 & $8.15 \pm 0.04$ & $5.31 \pm 0.09$ & $13.46 \pm 0.09$ & $100 \pm 0$ & $13.46 \pm 0.09$ \\
\hline & 0.5 & $8.61 \pm 0.07$ & $5.54 \pm 0.11$ & $14.14 \pm 0.17$ & $100 \pm 0$ & $14.14 \pm 0.17$ \\
\hline & 1 & $8.32 \pm 0.02$ & $4.73 \pm 0.02$ & $13.04 \pm 0.03$ & $100 \pm 0$ & $13.04 \pm 0.03$ \\
\hline & 1.5 & $6.74 \pm 0.15$ & $3.94 \pm 0.02$ & $10.67 \pm 0.16$ & $86 \pm 8.94$ & $9.19 \pm 1.06$ \\
\hline & 2 & $5.36 \pm 0.05$ & $3.24 \pm 0.09$ & $8.71 \pm 0.11$ & $80 \pm 10$ & $6.89 \pm 0.91$ \\
\hline \multirow{6}{*}{ Okra } & Control & $2.48 \pm 0.1$ & $1.21 \pm 0.03$ & $8.76 \pm 0.14$ & $76 \pm 5.48$ & $2.80 \pm 0.28$ \\
\hline & 0.1 & $3.58 \pm 0.04$ & $2.11 \pm 0.06$ & $13.46 \pm 0.09$ & $94 \pm 5.48$ & $5.35 \pm 0.35$ \\
\hline & 0.5 & $3.59 \pm 0.07$ & $2.02 \pm 0.01$ & $14.14 \pm 0.17$ & $96 \pm 5.48$ & $5.39 \pm 0.43$ \\
\hline & 1 & $2.79 \pm 0.13$ & $1.79 \pm 0.15$ & $13.04 \pm 0.03$ & $86 \pm 5.48$ & $3.94 \pm 0.47$ \\
\hline & 1.5 & $2.18 \pm 0.11$ & $1.02 \pm 0.05$ & $10.67 \pm 0.16$ & $74 \pm 5.48$ & $2.37 \pm 0.24$ \\
\hline & 2 & $1.91 \pm 0.04$ & $0.66 \pm 0.23$ & $8.71 \pm 10.94$ & $62 \pm 4.47$ & $1.91 \pm 0.47$ \\
\hline
\end{tabular}

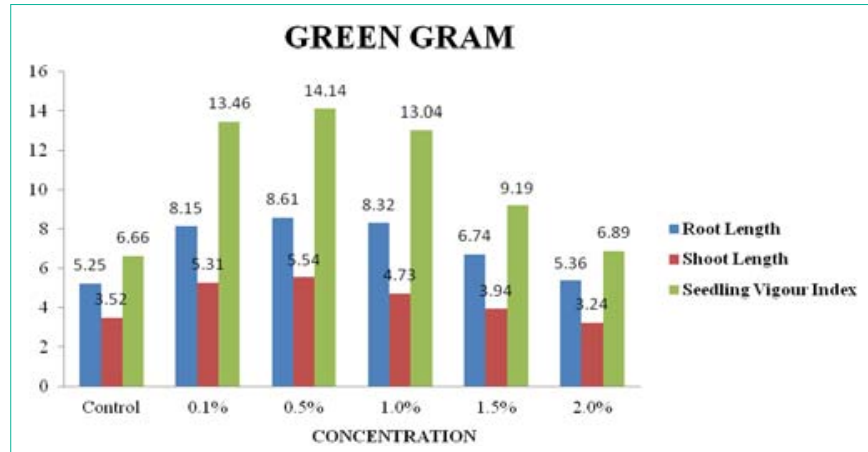

Figure 2: Different Concentration of Fish Hydrolysate on germination of Green gram.

4. Amino acid profile of fish hydrolysate extracts (Probiotic culture) is illustrated in Table 5. The overall response to DFH treatment by each extract was different. When comparing $3^{\text {rd }}$ and $7^{\text {th }}$ day of DFH almost all the amino acid content is similar, only 2-5 amino acids increased on $7^{\text {th }}$ day when compared with $3^{\text {rd }}$ day. But on the other hand, amino acid content of DFH decreased on $10^{\text {th }}$ day.

\section{Discussion}

Liquid produces obtained from fish by proteolytic enzymes or probiotics under various conditions of digestion results in fish protein hydrolysates. Requirement of alternative protein source has increased all around world over last decade. High quality proteins are available in enormous amounts from fish, fish protein hydrolysate and their value of importance has been increased by using them as a food supplement, bio-organic manure and liquid bio fertilizer. As a typical side effect of the fisheries business, FPH is known to be wealthy in amino acids basic to Proline metabolism [3]. Numerous investigations detailed

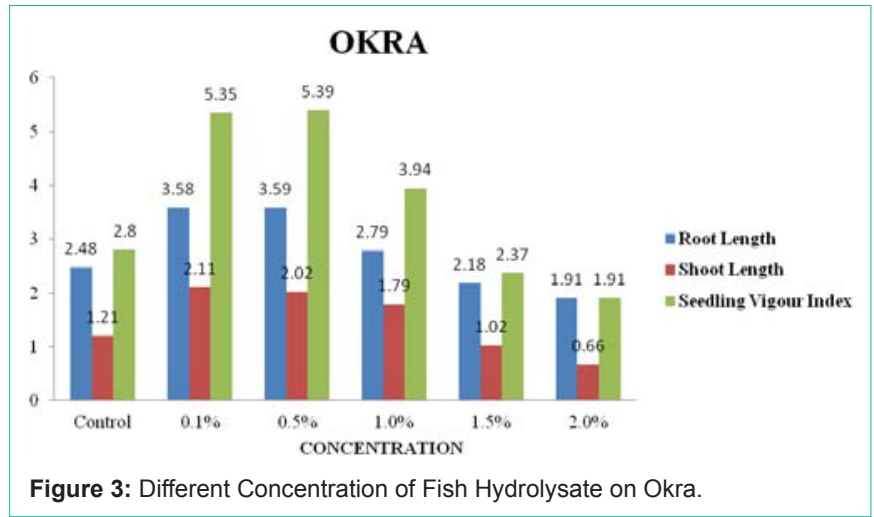

the organic action of different fish protein hydrolysates in vivo and in vitro by methods for their bioactive peptides [26-29]. Scientists explained the protein substance of fish protein hydrolysates went between $60 \%$ to $90 \%$ of complete arrangement [30-38]. Fish protein hydrolysates have been accounted for to show variation in their amino corrosive organization $[34,39,40]$. As a run of the mill reaction of the fisheries business, FPH is known to be well off in amino acids fundamental to proline metabolism [3]. Various examinations point by point the normal development of various fish protein hydrolysates in vivo and in vitro by strategies for their bioactive peptides [26-29].

The variety in amino corrosive creation of various fish protein hydrolysates for the most part relies upon a few factors, for example, crude material, catalyst source, and hydrolysis conditions [41,42]. Fish protein hydrolysate production using bacterial fermentation is better than all other mode of actions. Bacterial fermentation initiated by adding sugar or molasses as a substrate which helps to grow lactic acid, antibiotics which combine eliminate spoilage bacteria and 
Table 4: Typical analysis report (Hydrolysate and Residue) for digested dry fish using papain enzyme and probiotic.

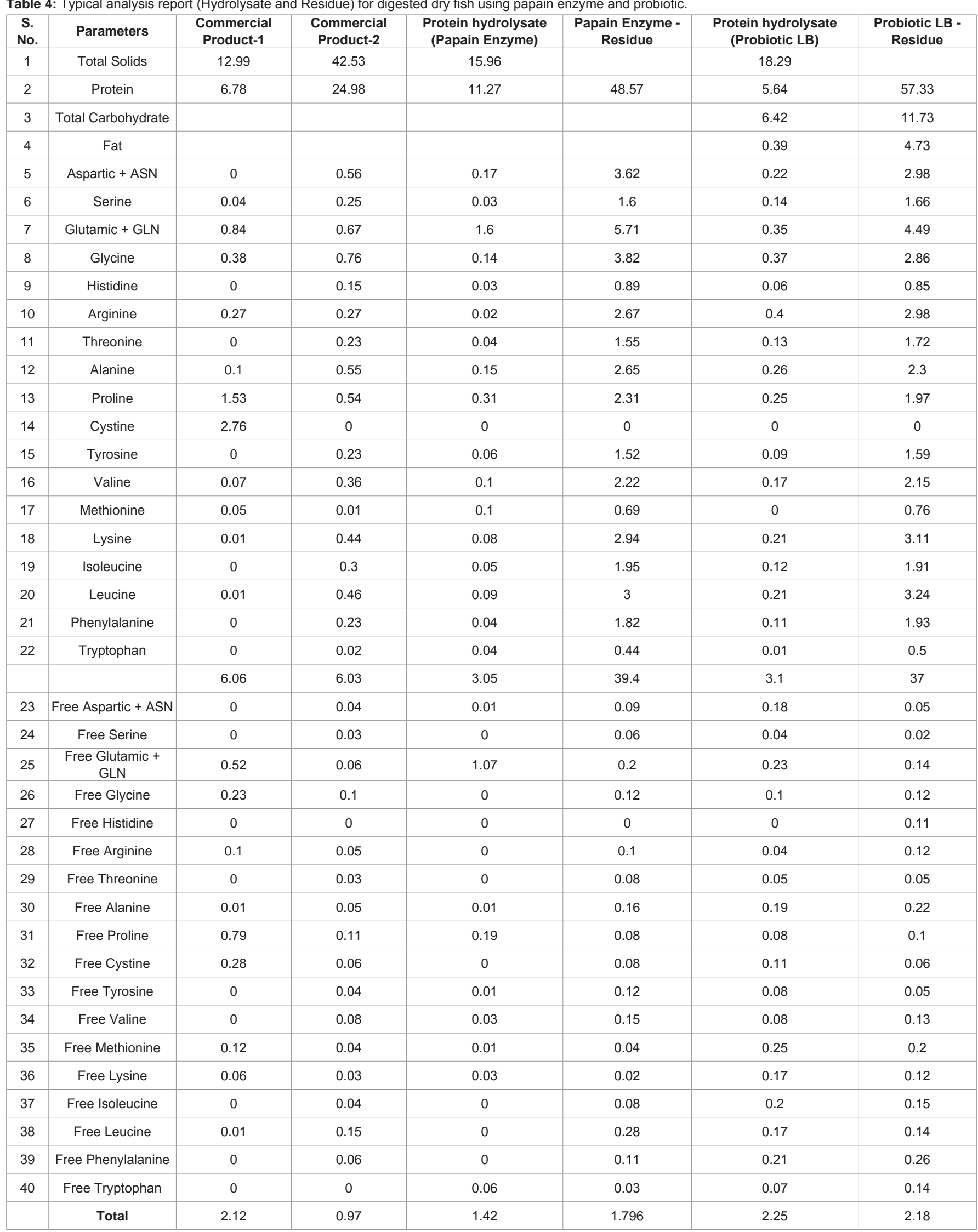


Table 5: Amino acid profile content of DFH on different time periods of extract.

\begin{tabular}{|c|c|c|c|c|c|c|}
\hline $\begin{array}{c}\text { Amino Acid } \\
\text { Profile }\end{array}$ & $\mathbf{Q W}$ & $\mathbf{3}^{\text {rd }}$ Day & $\mathbf{7}^{\text {th }}$ Day & $\mathbf{1} \mathbf{0}^{\text {th }}$ Day & Residue & $\begin{array}{c}\text { Raw } \\
\text { Material }\end{array}$ \\
\hline Aspartic acid & 13.39 & 10.68 & 12.58 & 0.73 & 6.75 & 86.66 \\
\hline Glutamic Acid & 0 & 2.62 & 3.02 & 14.25 & 11.91 & 0 \\
\hline Asparagine & 0.9 & 0 & 0 & 0 & 0 & 0 \\
\hline Serine & 0.79 & 0 & 0 & 1.52 & 0 & 0.99 \\
\hline Glutamine & 0 & 0 & 0 & 0 & 0 & 0 \\
\hline Histidine & 10.92 & 4.483 & 5.881 & 1.99 & 0 & 6.06 \\
\hline Glycine & 0 & 1.39 & 2.12 & 2.15 & 0 & 0 \\
\hline Threonine & 168.51 & 174.37 & 280.96 & 0 & 177.24 & 218.19 \\
\hline Arginine & 13.46 & 8.09 & 7.06 & 6.01 & 6.29 & 15.9 \\
\hline Alanine & 0 & 0.76 & 1.04 & 1.63 & 323.91 & 189.85 \\
\hline Tyrosine & 11.62 & 2.52 & 2.26 & 1.64 & 0 & 0 \\
\hline Cysteine & 2.76 & 5.5 & 6.33 & 6.32 & 3.58 & 3.63 \\
\hline Valine & 4.74 & 5 & 4.51 & 2.63 & 2.46 & 4.69 \\
\hline Methionine & 83.97 & 53.39 & 57.08 & 56.07 & 95.18 & 93.73 \\
\hline Tryptophan & 3.28 & 8.25 & 7.42 & 4.45 & 7.59 & 3.786 \\
\hline Phenylalanine & 1.93 & 5.46 & 4.08 & 6.37 & 2.98 & 1.28 \\
\hline Isoleucine & 8.63 & 13.56 & 19.75 & 17.61 & 18.56 & 9.57 \\
\hline Leucine & 35.62 & 204.23 & 208.88 & 183.97 & 14.93 & 37.05 \\
\hline Lysine & 2.95 & 7.5 & 6.56 & 1.32 & 0 & 0.86 \\
\hline Hydroxyproline & 28.81 & 2.83 & 3.15 & 1.8 & 3.56 & 33.93 \\
\hline Proline & 26.17 & 8.48 & 10.88 & 15.78 & 11.83 & 24.63 \\
\hline Total amt of AA & 418.45 & 519.11 & 643.56 & 326.24 & 686.77 & 730.806 \\
\hline & & & & & 0 \\
\hline
\end{tabular}

helps preservation effect. Fish protein hydrolysate using proteolytic enzyme such as papain helps to break down organic molecules like polypeptides, which is made of amino acids. Papain (Carica papaya L.) are naturally found in papaya and the unique structure of papain valuable for different purposes. Silver belly (Liognatus splendens) were more abundant in the area of coastal region of Rameswaram and are the only predominate by catch fish used in diets as significant proportions around $10-20 \%$ of dry weight without de-oiling. Silver belly accounts high quality protein content ranges $57.71 \%$ in commercial available fishmeal. Fat and protein content of silver belly accounts $2.9 \%$ and $16.5 \%$ studies on the effect of fish protein hydrolysate using enzyme and probiotics were made for the final product of liquid fish protein hydrolysate in various concentrations on seed germination. Past reports have recommended that cell reinforcement phenolic mixes may assume a job in advancing pea seedling improvement 17,43 ]. In present study, production of novel dry fish hydrolysate from silver belly using enzyme and bacteria were well demonstrated and their efficacy for plant growth promoters on seed germination carried out. Therefore the use of dry fish protein hydrolysate with $0.5 \%$ concentration as optimum to make good plant growth promoter as an efficient ecofriendly to the available conventional chemical fertilizers.

\section{Acknowledgements}

Mr. Abhiram Seth, MD and Mr. Tanmaye Seth, Director of AquAgri Processing Private Limited are gratefully acknowledged for their constant encouragement and facilities created to carry out the present investigation.

\section{References}

1. Rebeca BD, Pena-Vera MT, Diaz-Casteneda M. Production of fish protein hydrolysates with bacterial proteases; yield and nutritional value. J. Food Sci. 1991; 56: 309.

2. FAO. Food and Agricultural Organization Yearbook, Fishery Statistics, Rome, Italy. 1986.

3. Mackie IM. Fish protein hydrolysates. Proc. Biochem. 1982; 17: 26-29.

4. Frederick L, Harris R, Peterson L, Kehrmeyer S. The compost solution to dockside fish wastes. University of Wisconsin, Sea grant institute, USA. 1989.

5. Liao PH, Jones L, Lau AK, Walkmyer S, Egan S, Holbek N. Bioresource Technol. 1997; 59: 163

6. Kinnunen RE, Gould MC, Cambier P. Composting Commercial Fish Processing Waste from Fish Caught in the Michigan Waters of the Great Lakes. Michigan State University Extension, USA. 2005.

7. Gowen RJ. Aquaculture and the environment. In: Aquaculture and the environment (edited by N Depaw \& J Joyce). Ghent: European Aquaculture Society Special ff Publications. 1991; 16: 30-38.

8. Pillay TVR. Aquaculture and the Environment. London: Blacjwell Scientific Publications. 1991: 26-45.

9. FOC. The state of world fisheries and aquaculture. Fisheries and Aquaculture Department, Food and Agriculture Organization of the United Nations, Rome, Italy. 2012.

10. Tchoukanova N, Gonzalez M, Poirier S. Best Management Practices: Marine Products Processing. The Fisheries and Marine Products Division of the Coastal Zones Research institute Inc. 2012.

11. Suvanich V, Ghaedian R, Chanamani R. Prediction of proximate fish composition from ultrasonic properties: catfish. Cod, flounder, mackerel and salmon. Food Sci. 2006; 63: 966-968.

12. Leu SS, Jhaveri SN, Karakoltsidis PA, Constantinidies SM. Atlantic Mackerel (Scomber scombrus $L$ ): Seasonal variation in proximate composition and distribution of chemical nutrients. J. Food Sci. 1981; 46: 1635-1638.

13. Haaland H, Arnesen E, Njaa LR. Amino acid composition of whole mackerel (Scomber scombrus) stored anaerobically at $20^{\circ} \mathrm{C}$ and at $2^{\circ} \mathrm{C}$. Int. J. Food Sci and Tech. 1990; 25: 82-87.

14. Hamid AA, Baker J, Bhee GH. Nutritional quality of spray dried protein hydrolysate from black Tilapia (Oreochromis mossambicus). Food chemistry. 2002; 78: 69-74.

15. AMEC. Management of wastes from Atlantic seafood processing Operations. AMEC Earth and Environment Limited, Dartmouth, Nova Scotia, Canada. 2003.

16. Gopalan C, Rama sastri BV, Balasubramanin SC. Nutritive value of Indian foods. National Institute of Nutrition, ICMR, Hyderabad. 2004.

17. Andarwulan N, Shetty K. Improvement of pea (Pisum sativum) seed vigour response by fish protein hydrolysates in combination with acetyl salicylic acid. Process Biochem. 1999; 35: 159-165.

18. Gildberg A. Enzymic processing of marine raw materials. Process Biochemistry. 1993; 1: 1-15.

19. Chalamaiah M, Dinesh Kumar B, Hemalatha R, Jyothirmayi T. Fish protein hydrolysates: Proximate composition, amino acid composition, antioxidant activities and applications: A review. Food Chem. 2012; 135: 3020-3038.

20. Akiyo Horii, Patrick McCue, Kalidas Shetty. Seed Vigour studies in corn, soybean and tomato in response to fish protein hydrolysates and consequences on phenolic linked responses. Bioresource Tech. 2007; 98: 2170-2177.

21. Deesle WD, Cheryan M. Functional properties of soy protein hydrolysates from a continuous ultrafilteration reactor. J. Agri and Food chem. 1988; 36: 26-31.

22. Shahidi F, Han XQ, Synowiecki J. Production and characteristics of protein 
hydrolysates from capelin (Mallotus villosus). Food chem. 1995; 53: 285-293.

23. Vidotti RM, Elisabete Maria MV, Dalton Jose, et al. Amino acid composition of processed fish silage using different raw materials. Animal Feed Science and Technology. 2003; 105: 199-204.

24. AOAC. Official methods of analysis ( $16^{\text {th }}$ ed.). Washington, DC: Association of Official Analytical Chemists. 2005

25. Henderson JW, Ricker RD, Bidlingmeyer BA, Woodward C. Agilent Technical Note 5980-1193E. 2000

26. Duartea J, Vinderola G, Ritzc B, Perdigon G, Matara C. Immunomodulating capacity of commercial fish protein hydrolysate for diet supplementation. Immunobiology. 2006; 211: 341-350.

27. Je JY, Park PJ, Kwon JY, Kim SK. A novel angiotensin I converting enzyme inhibitory peptide from Alaska pollack (Theragra chalcogramma) frame protein hydrolysate. J. Agric. Food Chem. 2004; 52: 7842-7845.

28. Liaset B, Madsen L, Hao Q, Criales G, Mellgren G, Marschall H, et al. Fish protein hydrolysate elevates plasma bile acids and reduces visceral adipose tissue mass in rats. Biochimica et Biophysica Acta. 2009; 1791: 254-262.

29. Picot L, Bordenave S, Didelot S, Fruitier-Arnaudin I, Sannier F, Thorkelsson $\mathrm{G}$, et al. Antiproliferative activity of fish protein hydrolysates on human breas cancer cell lines. Process Biochem. 2006; 41: 1217-1222.

30. Choi YJ, Hur S, Choi BD, Konno K, Park JW. Enzymatic hydrolysis of recovered protein from frozen small croaker and functional properties of its hydrolysates. J. Food Sci. 2009; 74: C17-C24.

31. Dong Y, Sheng G, Fu J \& Wen K. Chemical characterization and anti-anaemia activity of fish protein hydrolysate from Saurida elongate. J. Sci. Food Agric 2005; 85: 2033-2039.

32. Khantaphant S, Benjakul S \& Kishimura H. Antioxidative and ACE inhibitory activities of protein hydrolysates from the muscle of brownstripe red snapper prepared using pyloric caeca and commercial proteases. Process Biochem. 2011; 46: 318-327.

33. Nilsang S, Lertsiri S, Suphantharika M \& Assavanig A. Optimization of enzymatic hydrolysis of fish soluble concentrate by commercial proteases. J. Food Eng. 2005; 70: 571-578.
34. Ovissipour M, Abedian Kenari A, Motamedzadegan A, Nazari RM Optimization of enzymatic hydrolysis of visceral waste proteins of Yellowfin Tuna (Thunnus albacares). Food Bioprocess Tech. 2010.

35. Pacheco-Aguilar R, Mazorra-Manzano MA, Ramirez-Suarez JC. Functiona properties of fish protein hydrolysates from Pacific whiting (Merluccius productus) muscle produced by a commercial protease. Food Chem. 2008; 109: 782-789.

36. Sathivel S, Bechtel PJ, Babbitt J, Smiley S, Crapo C, Reppond KD, et al. Biochemical and functional properties of Herring (Clupea harengus) byproduct hydrolysates. J. Food Sci. 2003; 68: 2196-2200.

37. Souissi N, Bougatef A, Triki-Ellouz Y, Nasri M. Biochemical and functional properties of Sardinelle (Sardinella aurita) by-product hydrolysates. Food Tech. Biotech. 2007; 45: 187-194.

38. Thiansilakul Y, Benjakul S, Shahidi F. Compositions, functional properties and antioxidative activity of protein hydrolysates prepared from round scad (Decapterus maruadsi). Food Chem. 2007; 103: 1385-1394.

39. Bhaskar N, Benila T, Radha C, Lalitha RG. Optimization of enzymatic hydrolysis of visceral waste proteins of catla (Catla catla) for preparing protein hydrolysates using a commercial protease. Bioresource Tech. 2008; 99: 335343.

40. Wasswa J, Tang J, Gu X, Yuan X. Influence of the extent of enzymatic hydrolysis on the functional properties of protein hydrolysate from grass carp (Ctenopharyngodon idella) skin. Food Chem. 2007; 104: 1698-1704.

41. Klompong V, Benjakul S, Yachai M, Visessanguan W, Shahidi F, Hayes KD. Amino acid composition and antioxidative peptides from protein hydrolysates of yellow stripe trevally (Selaroides leptolepis). J. Food Sci. 2009a; 74: C126-C133.

42. Klompong V, Benjakul S, Kantachote D, Shahidi F. Characteristics and use of Yellow Stripe Trevally hydrolysate as culture media. J. Food Sci. 2009b; 74: S219-S225.

43. Zheng Z, Shetty K. Effect of apple pomace-based Trichoderma inoculations on seedling vigour in pea (Pisum sativam) germinated in potting soil. Process Biochem. 1999; 34: 731-735. 